\title{
Development of micro-propagation and mini cutting protocol for fast growing Melia, Dalbergia and Eucalyptus clones for pulpwood and bio-energy plantations
}

\author{
Senniappan Chinnaraj, C Malimuthu \\ From IUFRO Tree Biotechnology Conference 2011: From Genomes to Integration and Delivery \\ Arraial d'Ajuda, Bahia, Brazil. 26 June - 2 July 2011
}

Per capita paper consumption is only $9.2 \mathrm{~kg}$ in India, which is much lower when compared to other neighboring developing economies, such as, China (42 kg) \& Indonesia $(23 \mathrm{~kg})$. Currently Indian economy is growing by $7.5 \%$ per annum. Along with economical growth, the paper demand is also expected to grow and cross 20 million tonnes per annum by 2020 from current 10 million tonnes. Availability \& quality of raw material, non availability of land for pulp wood plantations, alternate use of pulp wood for other uses like bio-energy and regulations to increase green energy use in mill operations would become major challenge for Indian paper industry's survival and growth. To face these changes effectively, paper industries in India initiated many social forestry models and brought 4,00,000 hectors under pulp wood plantations. This has helped pulp wood availability and reduced the fibrous raw material shortage to some level but it is not enough to meet the growth.

Tamil Nadu Newsprint and Paper Limited (TNPL) is state owned integrated pulp and paper industry situated in southern most state of India and produce around $4,00,000$ tons of paper per annum. TNPL has 300 Tonnes per day (TPD) hardwood fibreline along with 550 TPD bagasse fibre line to meet its pulp requirement. TNPL had setup biotechnology and bio-energy research facility under the existing R \& D Department to work on identification, selection and multiplication of improved pulpwood clones of Eucalyptus and other alternate fast growing hardwood species through modern biotechnological methods to meet pulpwood and

\footnotetext{
* Correspondence: chinnaraj.s@tnpl.co.in

S.V. Subrahmanyam Tamil Nadu Newsprint and Papers Ltd, India
}

also bio-energy need. The plant tissue culture facility has one million plants per annum capacity and optimized protocols for many improved Eucalyptus pulp wood clones to use as clonal mother plants at Clonal Production and Research Centre of Plantation Department using mini cutting process. TNPL clonal production facility has capacity of 15 million seedlings per annum and already covered 52,000 acres of pulp wood plantation and plan to cover additional 15,000 acres every year.

As a part ongoing research activity, one Melia dubia clone for bio-energy/pulpwood and one Dalbergia sissoo clone and three clones of eucalyptus, (each one from $E$. urograndis, E. tereticornis, and E. camaldulensis), were identified based on its biomass productivity, as well as, pulp quality and yield. Micro-propagation protocol was optimized for all the above five clones with modified MS medium with various concentrations of cytokinin and auxin. The seedlings produced using micro-propagation were used as mother plants for clonal mini garden in the concrete sand beds where the nutrient requirements where optimized for further multiplication using mini cutting process. The results of above study is presented and discussed in this paper.

Wood and pulp properties of all selected Melia dubia, Dalbergia sissoo, E. urograndis, E. tereticornis, and E. camaldulensis clones are presented in the Table 1 along with reference Eucalyptus pulp wood used in the mill. All the selected clones show high yield and strength properties. However, Melia dubia is not preferred as pulpwood due to low bulk density which would result in less through-put in fibreline. But it can be exploited for bio-energy applications especially for biomass 
Table 1 Results of wood pulping and pulp properties of selected pulpwood and bio-energy clones

\begin{tabular}{|c|c|c|c|c|c|c|c|}
\hline Parameters & Units & $\begin{array}{l}\text { Melia } \\
\text { dubia }\end{array}$ & $\begin{array}{l}\text { Dalbergia } \\
\text { sissoo }\end{array}$ & $\begin{array}{l}\text { Eucalyptus } \\
\text { urograndis }\end{array}$ & $\begin{array}{l}\text { Eucalyptus } \\
\text { tereticornis }\end{array}$ & $\begin{array}{l}\text { Eucalyptus } \\
\text { camaldulensis }\end{array}$ & Reference \\
\hline Bulk density & $\mathrm{kg} / \mathrm{m} 3$ & 136 & 230 & 184 & 213 & 220 & 225 \\
\hline Basic density & $\mathrm{kg} / \mathrm{m} 3$ & 318 & 547 & 402 & 502 & 520 & 510 \\
\hline Chemical addition & $\%$ & 15.0 & 15.0 & 15.0 & 15.0 & 15.0 & 15.0 \\
\hline Screen rejects & $\%$ & 0.8 & 0.7 & 0.2 & 0.2 & 0.8 & 0.8 \\
\hline Screened pulp yield & $\%$ & 46.5 & 47.0 & 46.6 & 47.3 & 47.5 & 44.2 \\
\hline Kappa Number & & 21.6 & 18.5 & 20.4 & 19.1 & 19.7 & 25.3 \\
\hline Brightness & $\%$ ISO & 27.8 & 30.7 & 29.1 & 34.9 & 30.5 & 24.2 \\
\hline \multicolumn{8}{|c|}{$\begin{array}{l}\text { Unbleached Strength properties at } \\
300 \mathrm{ml} \mathrm{CSF}\end{array}$} \\
\hline Tensile index & $\mathrm{Nm} / \mathrm{g}$ & 94.2 & 79.0 & 98.0 & 92.0 & 95.0 & 74.0 \\
\hline Tear index & $\begin{array}{l}\mathrm{mN} . \\
\mathrm{m} 2 / \mathrm{g}\end{array}$ & 11.9 & 9.3 & 8.7 & 10.3 & 9.5 & 8.2 \\
\hline Burst index & $\begin{array}{l}\mathrm{kPa} \\
\mathrm{m} 2 / \mathrm{g}\end{array}$ & 6.4 & 5.6 & 6.9 & 6.5 & 5.6 & 5.1 \\
\hline
\end{tabular}

gasification to generate producer gas and use in Lime Kiln to replace fuel oil and also for other wood product applications. All the selected clones give approximately minimum $2.5 \%$ more pulp yield with improved pulp properties when compared reference pulpwood currently used in the mill. Higher pulp yield would definitely give better economy and environmental performance of mill operations. For example, $1 \%$ yield increase would result in annual savings of INR 35.0 million in pulp wood cost for mill of our size i.e. 300 TPD. Therefore, for $2.5 \%$ yield increase would result in annual saving of around INR 87.5 million apart from chemical saving and other environmental benefits.

To take all the selected clones from lab to land in a short period, micro-propagation and mini cutting protocols were optimized. The results are presented in the Table 2. E.tereticornis clone found to perform well during initiation, elongation and hardening. On the other

Table 2 Results of micro-propagation and mini cutting studies of selected pulpwood and bio-energy clones

\begin{tabular}{|c|c|c|c|c|c|c|}
\hline Parameters & Units & Melia dubia & $\begin{array}{l}\text { Dalbergia } \\
\text { sissoo }\end{array}$ & $\begin{array}{l}\text { Eucalyptus } \\
\text { urograndis }\end{array}$ & $\begin{array}{l}\text { Eucalyptus } \\
\text { tereticornis }\end{array}$ & $\begin{array}{l}\text { Eucalyptus } \\
\text { camaldulensis }\end{array}$ \\
\hline \multicolumn{7}{|l|}{ Imitation } \\
\hline Optimum Benzylaminopurine & mg/lit. & 1.0 & 1.0 & 1.5 & 0.5 & 0.5 \\
\hline Initiation rate & $\%$ & 56 & 36 & 48 & 84 & 64 \\
\hline Average shoot length after 30 days & $\mathrm{cm}$ & 1.0 & 1.5 & 1.0 & 3.0 & 1.5 \\
\hline \multicolumn{7}{|l|}{ Multiplication } \\
\hline Optimum BAP & mg/lit. & 0.25 & 0.15 & 0.15 & 0.15 & 0.15 \\
\hline Average Number of shoots per clump & no & 2.0 & 3.0 & 32 & 24 & 15 \\
\hline Average shoot length & $\mathrm{cm}$ & 3.0 & 2.5 & 0.5 & 1.5 & 1.0 \\
\hline \multicolumn{7}{|l|}{ Elongation } \\
\hline Optimum Auxin & mg/lit. & 0.0 & 0.0 & 0.0 & $0.5(\mathrm{IAA})$ & 4.0 (NAA) \\
\hline Average Number of shoots per clump & no & 2.0 & 2.0 & 4.0 & 6.0 & 4.0 \\
\hline Average shoot length & $\mathrm{cm}$ & 5.0 & 5.0 & 3.0 & 7.0 & 4.0 \\
\hline \multicolumn{7}{|l|}{ Rooting } \\
\hline Optimum IBA & mg/lit. & 1.0 & 1.0 & 1.0 & 1.0 & 1.0 \\
\hline Average Number of roots per shoot & no & 4.0 & 4.0 & 8.0 & 7.0 & 5.0 \\
\hline Average shoot length & $\mathrm{cm}$ & 2.0 & 1.5 & 2.0 & 5.0 & 3.0 \\
\hline Rooting & $\%$ & 90 & 40 & 100 & 100 & 100 \\
\hline \multicolumn{7}{|l|}{ Hardening } \\
\hline Survival & $\%$ & 62 & 45 & 85 & 95 & 80 \\
\hline \multicolumn{7}{|l|}{ Mini cutting } \\
\hline Number of shoots per plant/cutting & no & 4.0 & 7.0 & 8.0 & 6.0 & 5.0 \\
\hline Rooting and survival & $\%$ & 70 & 63 & 79 & 86 & 73 \\
\hline
\end{tabular}


hand, E. urograndis found to perform well during multiplication and gave maximum number of shoots per clump. All the Eucalyptus clones found to perform well during the rooting. Melia dubia and Dalbergia sissoo are found to perform poor in micro-propagation compared to Eucalyptus. Seedlings produced by micropropagation are used for mini cutting experiments and results are presented in Table 2. E. urograndis produced more number of cuttings per plant per month followed byDalbergia sissoo, E.tereticornis E. camaldulensis and Melia dubia. Rooting and survival rate is also high for Eucalyptus clones when compared toDalbergia sissoo andMelia dubia.

Micro-propagation followed mini cutting protocol for propagation of all the above clones has been successfully adopted by mill for commercial production of quality seedling for mill's pulp wood and other plantation programme.

Published: 13 September 2011

doi:10.1186/1753-6561-5-S7-P131
Cite this article as: Chinnaraj and Malimuthu: Development of micropropagation and mini cutting protocol for fast growing Melia, Dalbergia and Eucalyptus clones for pulpwood and bio-energy plantations. BMC Proceedings 2011 5(Suppl 7):P131.

Submit your next manuscript to BioMed Central and take full advantage of:

- Convenient online submission

- Thorough peer review

- No space constraints or color figure charges

- Immediate publication on acceptance

- Inclusion in PubMed, CAS, Scopus and Google Scholar

- Research which is freely available for redistribution

Submit your manuscript at www.biomedcentral.com/submit 